Institute of $\mathbf{F}_{\text {ood and }} \mathbf{A}_{\text {gricultural }} \mathbf{S}_{\text {ciences }}$

\title{
Early Weaning: a Management Alternative for Florida Beef Cattle Producers ${ }^{1}$
}

John Arthington ${ }^{2}$

\section{Introduction}

Professors from the University of Florida have been teaching the importance of cow body condition for many years. Florida producers realize that the nutritional value of their forages, in combination with poor winter yield, limits cow reproductive performance. Nevertheless, even today, low cow body condition is the number 1 reason for reduced conception rates and overall poor cowherd productivity. Cow body condition is a subjective estimate of the amount of fat cover on a cow and is the most reliable method for evaluating a nutritional program. Cows grazing pastures with inadequate forage availability or forage with low nutrient value will lose body condition if not provided with supplemental nutrients to meet their requirements. For moderate frame-score cows, one body condition score is equal to about 75 pounds of body weight. Body condition typically declines after calving, when the nutritional demands of the cow are at a maximum. It is during this time that supplemental nutrition is most needed. Research from the University of Florida has shown that cows with low body condition scores (less than or equal to 4.0 ) have a $30 \%$ reduction in pregnancy rate compared to cows in optimum body condition (5.0 to 6.0). Cows with low body condition score that do conceive often do so late in the breeding season. This increase in post-partum interval results in later calves the following year. The problem is most pronounced in young cows and heifers, whose nutritional demands are higher to support both lactation as well as their own continued growth. When managing these young cows, producers are faced with a limited number of options, including, 1) provide adequate nutrient-dense supplementation, 2) wean early to remove the nutritional demands associated with lactation, or 3 ) breed heifers at 3 years of age when their own growth demands are lessened.

\section{Early Weaning}

Early weaning may be a practical and profitable management consideration for Florida cow/calf operations. Research from Purdue University has shown that early weaning may decrease the post-partum anestrus period by 24 days. As early-weaned cows begin to stop lactating, their dry matter intake decreases. Recent results from our research have shown that early-weaned, first-calf heifers require approximately $50 \%$ less TDN to achieve and maintain a body condition score of 5.0

1. This document is AN131, one of a series of the Animal Sciences Department, Florida Cooperative Extension Service, Institute of Food and Agricultural Sciences, University of Florida. Original publication date March 2003. Visit the EDIS Web Site at http://edis.ifas.ufl.edu.

2. John Arthington, assistant professor, Animal Science, Range Cattle Research and Education Center, Cooperative Extension Service, Institute of Food and Agricultural Sciences, University of Florida, Gainesville, 32611

The Institute of Food and Agricultural Sciences is an equal opportunity/affirmative action employer authorized to provide research, educational information and other services only to individuals and institutions that function without regard to race, color, sex, age, handicap, or national origin. For information on obtaining other extension publications, contact your county Cooperative Extension Service office. Florida Cooperative Extension Service/Institute of Food and Agricultural Sciences/University of Florida/Christine Taylor Waddill, Dean. 
compared to lactating heifers of the same age (Figure 1). The intake values represented by these data show the amount of TDN consumed by a lactating first-calf heifer and her calf, compared to an early-weaned first-calf heifer without her calf (normal weaned). Combined with the highly efficient feed:gain ratios of early-weaned calves, these data show greater than a 40\% improvement in converting TDN into calf gain. These data have significant practical value to the productivity of Florida cowherds, especially for heifers and young cows. In any given year, the majority of females in a producer's "open" category are heifers and young cows. The use of early weaning will allow these females to regain their lost body condition, and do so with less forage and supplemental feed. The decrease in post-partum interval also means these females will become pregnant earlier in the upcoming breeding season and therefore produce calves that will be older and heavier at next year's weaning.

Early weaning also has positive implications on the value of calves post-weaning. In most Florida ranch settings, calves are shipped immediately after separation from the cow. When shipped as a complete group (not commingled) these calves typically perform well. Nevertheless, buyers have often discounted fresh-weaned calves due to the potential for stress-related disease. The use of early weaning, followed by 100 days of winter annual grazing, produces calves that have recovered from weaning stress and understand how to eat. Once received into the feed yard, these calves will likely have fewer incidences of illness.

Early weaning also has positive benefits beyond animal health and performance. Researchers from the University of Illinois have been investigating the effect of early weaning on carcass merit. They reported that early weaning improved the percentage of calves grading USDA Choice or higher by over $30 \%$ compared to normally weaned calves. In a comparison of weaning age (90, 150, or 210 days), they found that calves weaned at 90 days tended to produce higher quality carcasses. This year we will be finishing all our early-weaned calves, in addition to their normal-weaned contemporaries, at the Animal Sciences Research Feedlot at North Carolina State University, Raleigh. This collaboration will allow us to capture additional feedlot and carcass data on this management system, which will be reported in later updates.

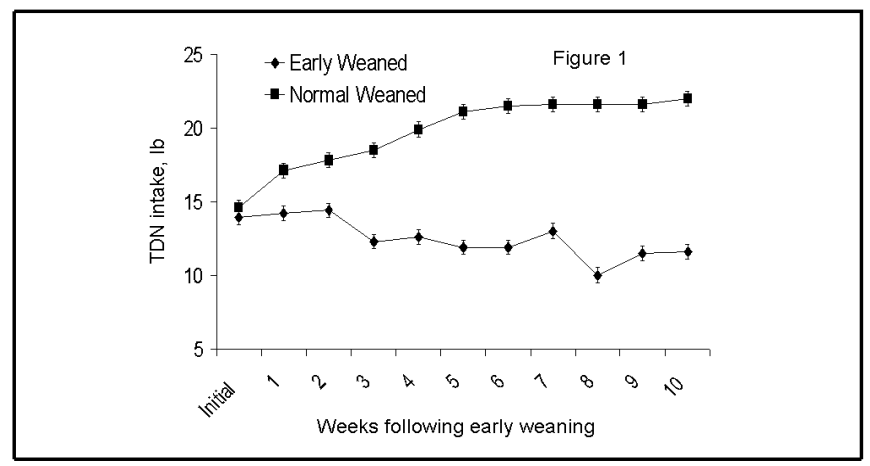

Figure 1. Early-weaned first-calf heifers need less TDN.

\section{Calf Nurseries}

Most of the research studying the effects of early weaning on cow and calf productivity has come from the midwest and high plains regions. At the time of early weaning, these producers are often without adequate pasture forage, therefore, their studies have focused on the use of dry lot feeding of the early-weaned calves. An opportunity to rear early-weaned calves on high-quality pasture forage should provide important value toward the costs of maintaining an early-weaned calf.

Producers may choose to market early-weaned calves immediately after weaning versus accepting the management of these young animals. The mild winters associated with Florida offer a unique opportunity to manage calves on a forage-based grazing system using ryegrass, a highly nutritious, winter annual forage. In the past, ryegrass has earned a bad reputation for being unreliable due to highly variable winter rainfall. In collaboration with Dr. Rob Kalmbacher, at the Range Cattle REC, we have been investigating the establishment of calf nurseries for the rearing of early-weaned calves. Calf nurseries consist of ryegrass grown on a selected piece of land that slopes from a lower wet area upward to a higher dry area. This provides a dedicated piece of land that should respond favorably to variation in rainfall: the higher land will yield better in wet winters and the lower in dry winters. Each nursery has a small area (approx. 1/2 acre) of bahiagrass sod where water, feed, and mineral are offered. We learned that hogs 
enjoy rooting through the nurseries; therefore, woven-wire fencing surrounds each nursery. Over the past three years, we have grazed early-weaned calves at an average stocking rate of 4 calves / acre. Despite dry winters in 2000 and 2001, this stocking rate turned out to be acceptable, as available forage often exceeded that which the calves could consume (Figure 2). We expect the optimal stocking rate to be around 4 to 5 calves/acre. At this rate, calf nurseries use a minimum of dedicated land. For example, using an early weaning rate of $10 \%$ (lactating cows with the lowest body condition) a 500-head cow herd would wean 50 early calves, and would require only 10 acres of land for the calf nursery.

In our system, calves are born in the fall (October / November) and weaned at the start of the breeding season on January 1, at an average age of 70 days. 'Jumbo' ryegrass is established on cultivated soil in mid-November. We prefer 'Jumbo' because tests have shown it grows later (approx. 30 days into the spring) compared to 'Gulf'. A complete fertilizer (20:5:15) is applied at emergence (300 lb/acre) and again at 45-day intervals. We can expect about 100 days of grazing lasting into April.

Ryegrass provides an excellent source of feed for calves. Using a feed:gain ratio of 4.2 to 1 , our calf nurseries provided 1.2 tons of ryegrass $\mathrm{DM} /$ acre, which was $81 \%$ digestible and contained $35 \%$ crude protein. To supplement the ryegrass, calves are provided with grain (16\% crude protein) at a targeted rate of $1.0 \%$ of body weight daily. Last year, our early-weaned calves had a higher ADG from the time of early weaning until the end of ryegrass grazing compared to their contemporaries left with their dams (Table 1). Throughout the entire ryegrass-grazing period (112 days), the early-weaned calves gained an average of $288 \mathrm{lb} / \mathrm{calf}(2.04 \mathrm{lb} /$ day $)$. Considering the total costs for ryegrass establishment, fertilizer, grain, mineral, and supplies, our overall cost of gain was $\$ 0.32 / \mathrm{lb}$.

Once early-weaned calves were moved onto perennial, summer limpograss pastures, their performance declined rapidly. From May 15 to weaning (August 6), early-weaned calves had an ADG of $0.66 \mathrm{lb} /$ day less than normal-weaned. This decline in performance resulted in a higher overall
ADG for normal-weaned compared to early-weaned calves from January to August (Table 1). These data would support the marketing of early-weaned calves in late April or early May. Historically, calf markets are at their highest this time of the year.

Cow performance is improved by early weaning. Last year, early weaning resulted in heavier cows in better condition at the time of normal weaning (Tables 2 and 3). This improvement in body condition was associated with a higher pregnancy rate and 21-day-shorter calving interval for early-weaned versus normal-weaned cows (89.5 vs. $50.0 \%$ pregnant for early- and normal-weaned, respectively).

The use of early weaning is an effective management tool for optimizing reproductive performance of young cows. Our initial research indicates that early weaning will improve cow body condition by over 2 points (approx. $150 \mathrm{lb}$ ) resulting in a $30 \%$ improvement in pregnancy rate. Establishing dedicated calf nurseries will provide Florida producers with the ability to optimize early-weaned calf performance, while capitalizing on low cost of gain and favorable spring markets.

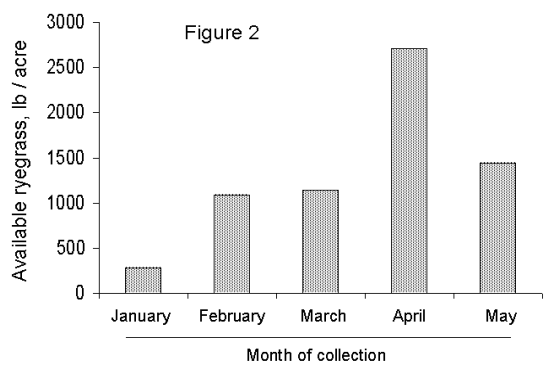

Figure 2. Calf nurseries produce sufficient forage, even in dry winters.

\section{Common Questions on Early Weaning}

Since we have begun our research on this management topic, we have gotten many good questions from interested producers. Some of these questions have become common, so we have listed them in this article. 
1. Do we need to wean our calves before the start of the breeding season?

Answer: This is not essential. Actually, the start of the breeding season is a good time to consider which cows will be weaned early. Certainly, the sooner you can remove the calf, the sooner the cow will gain the nutritional benefits of not lactating. If you generally breed your heifers 30 days before the mature cows, then these calves will be plenty old enough to be weaned at the start of the breeding season on the following year. Calves need to be at least 60 days old before they should be weaned.

2. If I use early weaning as a management tool to improve young cow reproductive performance, won't I be selecting females with poor reproductive traits that would otherwise have been culled?

Answer: This has been an interesting question and one that truly illustrates our mindset on cow culling. Certainly poor reproductive performance is a trait that should be highest on our cull list. In the past, producers often were unable to cull for other poor cow traits because the number of cows available for culls was takenup by open females. Many of these were young cows that simply did not breed because of poor body condition. If they are weaned early, these females will become pregnant. You may still cull them the following year by using calving date as the culling criteria. In this manner, you've achieved the same outcome (culled cow), but now have a calf to market.

\section{I can't grow ryegrass!}

Answer: A 200-lb, early-weaned calf will only consume about 5 to $6 \mathrm{lb}$ of dry matter per day. We recommend a supplementation rate of $1.0 \%$ of body weight; therefore, the calf is only consuming 3 to $4 \mathrm{lb}$ of ryegrass dry matter daily. Most producer perceptions of ryegrass come from the attempt to graze mature cows. In contrast to the early-weaned calf, mature cows may consume $30 \mathrm{lb}$ of ryegrass DM daily, almost 10 times that of the calf. Therefore, even miserable-looking stands of ryegrass will support modest growth in early-weaned calves. Remember, supplemental energy feeds can be used if the ryegrass stand fails to support optimal growth. In many cases, the savings realized from reduced cow dry matter intake and improved reproductive performance may still offset the purchase of additional feed.

4. Which cows should be considered for early weaning?

Answer: The cows with low body condition are most likely to be the ones that will either not conceive or conceive late in the breeding season. Therefore, these should be the candidates for early weaning. Typically, these will be the young females of the herd.

5. After early weaning, can I sell my calves instead of feeding them on the ranch?

Answer: Sure, there is always a market for lightweight calves. However, our experiences suggest that keeping early-weaned calves at the ranch and rearing them on calf nurseries achieve highly efficient gains.

6. Why not just provide adequate feed and supplement to my lactating heifers so that they will maintain body condition and become pregnant?

Answer: Sure, this is fine. However, it is always more efficient to feed the calf directly versus feeding the cow so that she can feed the calf. These costs will be different for every situation depending on availability of pasture, quality of hay, and price of supplemental feed. 
Table 1. Effect of early calf weaning on calf growth

\begin{tabular}{|c|c|c|c|c|c|c|}
\hline & \multicolumn{3}{|c|}{ Calf body weight $^{1}$} & \multicolumn{3}{|c|}{ Calf ADG } \\
\hline \multirow[t]{2}{*}{ Treatment } & January & April & August & Jan. to April & April to Aug. & Jan. to Aug. \\
\hline & \multicolumn{3}{|c|}{------------- lb -------------- } & \multicolumn{3}{|c|}{---------------- lb ----------------- } \\
\hline Control & 192 & 326 & 509 & 1.48 & 1.87 & 1.68 \\
\hline Early-weaned $^{2}$ & 200 & 358 & 492 & 1.89 & 1.21 & 1.50 \\
\hline Pooled SEM & 4.6 & 6.4 & 10.8 & 0.04 & 0.07 & 0.04 \\
\hline$P=$ & 0.26 & 0.005 & 0.28 & $<0.001$ & $<0.001$ & 0.006 \\
\hline \multicolumn{7}{|c|}{$\begin{array}{l}1 \text { Individual calf body weight collected at the time of early weaning (January 23), mid-spring (April } 17 \text { and } 24 \text { for } \\
\text { early-weaned and control, respectively) and at normal weaning (July } 31 \text { and August } 8 \text { for early-weaned and control, } \\
\text { respectively). }\end{array}$} \\
\hline
\end{tabular}

Table 2. Effect of early calf weaning on cow body weight

\begin{tabular}{|c|c|c|c|c|c|c|}
\hline \multirow[b]{2}{*}{ Treatment } & \multicolumn{3}{|c|}{ Cow body weight ${ }^{1}$} & \multicolumn{3}{|c|}{ Cow body weight change } \\
\hline & January & April & August & Jan. to April & April to Aug. & Jan. to Aug. \\
\hline & \multicolumn{3}{|c|}{--------------- lb ---------------- } & \multicolumn{3}{|c|}{-------------------- lb -------------------- } \\
\hline Control & 941 & 919 & 982 & -22 & 63 & 41 \\
\hline Early-weaned & 907 & 954 & 1074 & 46 & 120 & 166 \\
\hline Pooled SEM & 19 & 18 & 22 & 12 & 13 & 16 \\
\hline$P=$ & 0.21 & 0.19 & 0.008 & $<0.001$ & 0.004 & $<0.001$ \\
\hline
\end{tabular}

Table 3. Effect of early calf weaning on cow body condition

\begin{tabular}{|c|c|c|c|c|c|c|}
\hline \multirow[b]{2}{*}{ Treatment } & \multicolumn{3}{|c|}{ Cow BCS ${ }^{1}$} & \multicolumn{3}{|c|}{ Cow BCS change } \\
\hline & January & April & August & Jan. to April & April to Aug. & Jan. to Aug. \\
\hline & \multicolumn{3}{|c|}{----- Scale (1 to 9) ------- } & \multicolumn{3}{|c|}{-------- Scale (1 to 9) ---------- } \\
\hline Control & 3.88 & 4.27 & 4.50 & 0.38 & 0.20 & 0.61 \\
\hline Early-weaned & 3.90 & 5.11 & 6.25 & 1.21 & 1.39 & 2.35 \\
\hline Pooled SEM & 0.18 & 0.14 & 0.19 & 0.12 & 0.17 & 0.21 \\
\hline$P=$ & 0.96 & $<0.001$ & $<0.001$ & $<0.001$ & $<0.001$ & $<0.001$ \\
\hline
\end{tabular}

